\title{
Improving the Results of Learning Ecosystem Themes Through Discovery Learning Models In Primary Schools
}

\author{
Annisa Hasna QA \\ SDN Tambakreja 09 Cilacap \\ annisahasnaqa@gmail.com
}

Article History

accepted 14/11/2020

approved $21 / 11 / 2020$

published 26/11/2020

\begin{abstract}
This research is a Classroom Action Research (CAR) which consists of two cycles. The research subjects were the fifth grade students of SDN Tambakreja 09 Cilacap, Central Java with a total of 23 students. The data technique used test and non-test techniques. The assessment instrument uses items. The data analysis used in the study included a comparative descriptive technique, namely a statistical technique by comparing the scores between cycles, the mean, the minimum score, the maximum, and the proportion. The results showed that the powerpoint video media with the discovery learning model could improve student learning outcomes in Theme 5 of the 5th grade ecosystem of SDN Tambakreja 09 Cilacap, this was evidenced by the learning outcomes in cycle I, namely 6 students out of 23 students or $26 \%$ who had not completed. while 17 students out of 23 students or $74 \%$ who completed. In cycle II, there were 5 students out of 23 students who had not completed, or $22 \%$, while 18 students out of 23 students or $78 \%$ who had completed it. With online learning using discovery learning model, student learning outcomes increased by $4 \%$ from cycle I to cycle II. The conclusion of this research is that online learning using powerpoint video media with discovery learning models can improve student learning outcomes in Theme 5 of the fifth grade ecosystem of SDN Tambakreja 09 Cilacap.
\end{abstract}

Keywords: learning media, discovery learning, learning outcomes

\begin{abstract}
Abstrak
Penelitian ini merupakan penelitian tindakan kelas (PTK) yang terdiri dari dua siklus. Subyek penelitian adalah siswa kelas V SDN Tambakreja 09 Cilacap Jawa Tengah dengan jumlah 23 siswa. Teknik pengumpulan data menggunakan teknik tes dan non tes. Adapun instrumen penilaiannya menggunakan butir-butir soal dan pengamatan rubrik penilaian. Analisa data yang digunakan dalam penelitian meliputi teknik deskriptif komparatif yakni teknik statistik dengan membandingkan skor antar siklus, mean, skor minimal, maksimal, dan persentase. Hasil penelitian bahwa media video powerpoint dengan model discovery learning dapat meningkatkan hasil belajar siswa pada Tema 5 ekosistem kelas V SDN Tambakreja 09 Cilacap, hal ini dibuktikan dari hasil belajar pada siklus I yaitu siswa yang belum tuntas sebanyak 6 siswa dari 23 siswa atau 26\%, sedangkan siswa yang tuntas sebanyak 17 siswa dari 23 siswa atau 74\%. Pada siklus II, siswa yang belum tuntas sebanyak 5 siswa dari 23 siswa atau $22 \%$, sedangkan siswa yang tuntas sebanyak 18 siswa dari 23 siswa atau $78 \%$. Dengan pembelajaran daring menggunakan model discovery learning hasil belajar siswa meningkat $4 \%$ dari siklus I ke siklus II. Kesimpulan dari penelitian ini adalah pembelajaran daring menggunakan media video powerpoint dengan model discovery learning dapat meningkatkan hasil belajar siswa pada Tema 5 ekosistem kelas V SDN Tambakreja 09 Cilacap.
\end{abstract}

Kata kunci: media pembelajaran, discovery learning, hasil belajar

Social, Humanities, and Education Studies (SHEs): Conference Series https://jurnal.uns.ac.id/shes

p-ISSN 2620-9284

e-ISSN 2620-9292

This work is licensed under a Creative Commons Attribution-ShareAlike 4.0 International License. 


\section{PENDAHULUAN}

Pada pembelajaran online (daring), peserta didik dapat menjadi kurang aktif dalam menyampaikan aspirasi dan pemikirannya, sehingga dapat mengakibatkan pembelajaran yang menjenuhkan. Seorang siswa yang mengalami kejenuhan dalam belajar akan memperoleh ketidakmajuan dalam hasil belajar.

Pendidikan merupakan salah satu bidang yang terus berkembang seiring dengan perkembangan ilmu pengetahuan dan teknologi (iptek). Oleh karena itu pembaharuan pada bidang pedidikan sangat penting untuk dilakukan Untuk mengatasi permasalahan di atas diperlukan perbaikan strategi pembelajaran yang mengarah pada tujuan pembelajaran dan materi belajar dengan kreatifitas guru dalam menggunakan model pembelajaran yang menarik dan menyenangkan. Dengan penggunaan media gambar melalui model discovery learning di kelas V SDN Tambakreja 09 Cilacap seperti yang dikemukan oleh Sudjana (2009:70) bahwa manfaat media gambar pada powerpoint dapat membantu dalam mengembangkan kemampuan siswa.

Gambar adalah media yang paling umum dipakai, Karena pengadaannya relatif lebih murah dan mudah didapat. Yang termasuk media gambar adalah kartun, komik, gambar tempel, dan foto. Menurut Wibawa dan Mukti (1993:60) bahwa gambar adalah termasuk media sederhana yang dapat digunakan dengan baik di SD, sebab gambar itu disukai siswa, murah harganya, tidak sulit mencarinya. Tujuan dari penggunaan media yaitu untuk membantu guru menyampaikan pesan-pesan secara lebih mudah kepada siswa sehingga siswa lebih menguasai pesan-pesan tersebut secara tepat dan akurat (Somantri, 2007:177).

Metode pembelajaran yang akan digunakan adalah discovery, di mana dalam metode pembelajaran ini siswa dapat menemukan sendiri pengetahuan yang berkaitan dengan kehidupan sehari-hari, dapat mengemukakan pendapatnya, saling menghargai pendapat teman, dan dapat menerapkannya dalam kehidupan bermasyarakat. Oleh sebab itu, metode discovery baik digunakan dalam pembelajaran.

Metode discovery memiliki kebaikan-kebaikan seperti diungkapkan oleh Suryabrata (2002), yaitu: Dianggap membantu siswa mengembangkan atau memperbanyak persediaan dan penguasaan ketrampilan dan proses kognitif siswa, andaikata siswa itu dilibatkan terus dalam penemuan terpimpin. Kekuatan dari proses penemuan datang dari usaha untuk menemukan, jadi seseorang belajar bagaimana belajar itu. Pengetahuan diperoleh dari strategi ini sangat pribadi sifatnya dan mungkin merupakan suatu pengetahuan yang sangat kukuh, dalam arti pendalaman dari pengertian retensi dan transfer. Strategi penemuan membangkitkan gairah pada siswa, misalnya siswa merasakan jerih payah penyelidikannya, menemukan keberhasilan dan kadangkadang kegagalan. Metode ini memberi kesempatan kepada siswa untuk bergerak maju sesuai dengan kemampuannya sendiri. Metode ini menyebabkan siswa mengarahkan sendiri cara belajarnya sehingga ia lebih merasa terlibat dan bermotivasi sendiri untuk belajar, paling sedikit pada suatu proyek penemuan khusus. Metode discovery dapat membantu memperkuat pribadi siswa dengan bertambahnya kepercayaan pada diri sendiri melalui proses-proses penemuan. Dapat memungkinkan siswa sanggup mengatasi kondisi yang mengecewakan. Strategi ini berpusat pada anak, misalnya memberi kesempatan pada siswa dan guru berpartisispasi sebagai sesama dalam situasi penemuan yang jawaban nya belum diketahui sebelumnya. Membantu perkembangan siswa menuju skeptisisme yang sehat untuk menemukan kebenaran akhir dan mutlak. SDN Tambakreja 09 menentukan kriteria 
ketuntasan minimal (KKM) pada mata pelajaran Tematik adalah 70. Sementara itu, hasil Tematik pada siswa kelas $\mathrm{V}$ yang berjumlah 23 anak rata-rata 70,25 yang mencapai KKM adalah (67\%) dan yang tidak mencapai KKM (33\%), ini berarti KKM belum tuntas, karena KKM dianggap tuntas apabila persentase nilai siswa yang mencapai KKM (75\%). Berdasarkan uraian di atas, maka peneliti ingin melakukan penelitian lebih lanjut dengan judul "MENINGKATKAN HASIL BELAJAR TEMA EKOSISTEM MELALUI MODEL DISCOVERY LEARNING PADA SISWA SEKOLAH DASAR"

Kemendikbud (2013:193) pembelajaran tematik dilaksanakan dengan menggunakan prinsip pembelajaran terpadu. Pembelajaran terpadu menggunakan tema sebagai pemersatu kegiatan pembelajaran yang memadukan beberapa mata pelajaran sekaligus dalam satu kali tatap muka, untuk memberikan pengalaman yang bermakna bagi siswa. Karena siswa dalam memahami sebuah konsep yang mereka pelajari selalu melalui pengalaman langsung dan menghubungkannya dengan konsep lain yang telah dikuasainya. Menurut Rusman (2012), pembelajaran tematik adalah model pembelajaran terpadu (integrated instruction) yang merupakan suatu sistem pembelajaran yang memungkinkan siswa baik secara individual maupun kelompok aktif menggali dan menemukan konsep serta prinsip- prinsip keilmuan secara holistik, bermakna dan otentik.

Berdasarkan beberapa pendapat di atas, penulis menyimpulkan bahwa pembelajaran tematik yaitu pembelajaran terpadu yang mengaitkan beberapa materi dari beberapa mata pelajaran dalam satu topik/ tema sehingga dapat memberikan pengalaman belajar yang bermakna.

Discovery dalam bahasa Indonesia berarti penemuan. Menurut pendapat Sund (1975), yang dikutip Suryabrata (2002) dinyatakan bahwa metode discovery adalah proses mental di mana siswa mengasimilasikan sesuatu konsep atau sesuatu prinsip. Proses mental tersebut misalnya. : mengamati, menggolong-golongkan, membuat dugaan, menjelaskan, mengukur, membuat kesimpulan, dan sebagainya. Yang dimaksud konsep misalnya : segi tiga, demokrasi, panas, energi, dan sebagainya. Sedangkan prinsip misalnya : logam apabila dipanasi mengembang, lingkungan berpengaruh terhadap kehidupan organisme, dan sebagainya. Sedangkan pendapat Gagne dan Berliner (1984) yang dikutip Moedjiono dan Moh. Dimyati (1991) dinyatakan bahwa metode discovery adalah metode di mana para siswa memerlukan penemuan konsep, prinsip dan pemecahan masalah untuk menjadi miliknya lebih dari pada sekedar menerimanya atau mendapatkannya dari seorang guru atau sebuah buku. Metode discovery menurut Rohani (2004) adalah metode yang berangkat dari suatu pandangan bahwa peserta didik sebagia subyek di samping sebagai obyek pembelajaran. Mereka memiliki kemampuan dasar untuk berkembang secara optimal sesuai dengan kemampuan yang mereka miliki. Proses pembelajaran harus dipandang sebagai suatu stimulus atau rangsangan yang dapat menantang peserta diidk untuk merasa terlibat atau berpartisipasi dalam aktifitas pembelajaran. Peranan guru hanyalah sebagai fasilitator dan pembimbing atau pemimpin pengajaran yang demokratis,sehingga diharapkan peserta didik lebih banyak melakukan kegiatan sendiri atau dalam bentuk kelompok memecahkan masalah atas bimbingan guru. Penggunaan teknik discovery ini guru berusaha meningkatkan aktifitas siswa dalam proses belajar mengajar.

Media pembelajaran berasal dari bahasa latin dan merupakan bentuk jamak dari kata medium yang secara harfiah berarti perantara atau pengantar. Sedangkan 
Menurut Asosiasi Pendidikan Nasional menyatakan media adalah bentuk-bentuk komunikasi baik tercetak maupun audiovisual serta peralatannya. Dimana media hedaknya dapat memanipulasi, dapat dilihat, didengar dan dibaca (Arief S Sadiman. Dkk, 2006:7). Media merupakan salah satu komponen komunikasi, yaitu sebagai pembawa pesan dari komunikator menuju komunikan (Criticos, 1996) dalam Santyasa, (2007). Video cd Intraktif multimedia atau disebut media pembelajaran cd interaktif berbasis video yang membutuhkan personal computers. Dalam video cd interaktif mutimedia ini adalah inovasi sebuah media yang menampilkan cara atau langkahlangkah pembuatan html web yang dapat mempermudah siswa untuk memahami dan mengaplikasikan, kemudian dapat merangsang siswa lebih aktif disisi lain siswa tidak perlu lagi sulit untuk membaca buku tingal mengikuti langkah cara pembuatan html web dengan media video cd Intraktif multimedia. Rayandra Asyhar (2012:74) berpendapat "video merupakan rekaman gambar dan suara dalam kaset pita video kedalam vita magnetik. Media Video dirancang untuk menghasilkan gambar yang realistis dunia sekitar kita".

Arsyad (2008) berpendapat bahwa konsep interaktif paling erat kaitannya dengan media berbasis komputer, interaksi dalam lingkungan pembelajaran berbasis komputer umumnya mengikuti tiga unsur yaitu: 1) urut-urutan instruksional yang dapat diurutkan, 2) jawaban/respon atau pekerjaan siswa dan 3) umpan balik yang dapat disesuaikan. Media interaktif biasanya mengacu pada produk dan layanan pada sistem berbasis komputer digital yang merespon tindakan pengguna dengan menyajikan konten seperti teks, grafik, animasi, video, audio, dan lain-lain. Camtasia studio merupakan perangkat lunak (software) yang dikembangkan oleh TechSmith Coorporation khusus bidang multimedia.

Camtasia Studio adalah program aplikasi yang dikemas untuk recording, editing, dan publishing dalam membuat video presentasi yang ada pada layar (screen) komputer. Camtasia studio adalah software untuk meng capture tampilan layar monitor, dengan ditambahi audio dan video, bisa juga kita gunakan untuk merekam hasil presentasi powerpoint ke dalam format video. Camtasia Studio dapat membantu dan melatih kita dalam menyampaikan serta berinteraksi dengan audiens. Camtasia Studio memiliki kemampuan untuk merekam suara yang ada dalam layar,termasuk kegiatan di desktop, presentasi powerpoint, narasi suara, dan webcam video. Camtasia Studio adalah salah satu solusi lengkap untuk menciptakan video profesional dan aktivitas desktop PC dengan cepat. Siapapun dapat merekam dan menciptakan satu pelajaran penuh video gerak atau presentasi. Video tutorial merupakan panduan tentang cara menjelaskan sesuatu, baik materi pembelajaran atau pelatihan (training) maupun proses pengoprasian suatu sistem (hardware dan software) yang dikemas dalam bentuk video. Format sajian ini merupakan multimedia pembelajaran yang dalam penyampaian materinya dilakukan secara tutorial, sebagaimana layaknya tutorial yang dilakukan oleh guru atau instruktur. Informasi yang berisi suatu konsep disajikan dengan teks, gambar, baik diam atau bergerak dan grafik. Pada saat yang tepat, yaitu ketika dianggap bahwa pengguna telah membaca menginterprestasikan dan menyerap konsep itu, diajukan serangkaian dan tugas. Jika jawaban atau respon siswa benar, kemudian dilanjutkan dengan materi berikutnya. jika jawaban atau respon siswa salah, maka siswa harus mengulang memahami konsep tersebut secara keseluruhan ataupun pada bagianbagian tertentu saja (remedial).

Kemudian pada bagian akhir biasanya akan diberikan serangkaian pertanyaan yang untuk mengukur tingkat pemahaman siswa atas konsep atau materi yang disampaikan. Tutorial atau tutoring adalah bantuan atau bimbingan belajar yang bersifat akademik oleh tutor kepada siswa untuk membantu kelancaran proses belajar madiri siswa secara perorangan atau kelompok berkaitan dengan materi ajar. Tutorial dilaksanakan secara tatap muka atau jarak jauh berdasarkan konsep belajar mandiri. Belajar mandiri dalam tutorial mengandung pengertian, bahwa tutorial merupakan 
bantuan belajar dalam upaya memicu dan memacu kemandirian, disiplin, dan inisiatif diri siswa dalam belajar dengan minimalisasi intervensi dari pihak pembelajar yang dikenal sebagai tutor. Prinsip pokok tutorial adalah "kemandirian siswa" . Tutorial tidak ada, jika kemandirian tidak ada. Jika siswa tidak belajar di rumah, dan datang ke tutorial dengan 'kepala kosong', maka yang terjadi adalah "pembelajaran" biasa, bukan tutorial. Jadi video tutorial adalah salah satu media pembelajaran yang berfungsi untuk melakukan pertukaran informasi antara pengirim dan penerima sehingga tercapainya suatu tujuan yang dikehendaki. Mata pelajaran pemrograman web Pemrograman web disini diambil dari 2 suku.

Tujuan penelitian ini adalah: mendeskripsikan langkah-langkah meningkatkan hasil belajar siswa pada tema 5 ekosistem melalui model pembelajaran discovery learning kelas V SDN Tambakreja 09 Cilacap; mengetahui penggunaan media pembelajaran dapat meningkatkan motivasi belajar siswa kelas V SDN Tambakreja 09 Cilacap; mengetahui penggunaan model discovery learning dapat meningkatkan hasil belajar siswa kelas $V$ SDN Tambakreja 09 Cilacap.

\section{METODE}

Penelitian Tindakan Kelas (PTK) yang digunakan peneliti adalah jenis PTK kolaboratif. PTK kolaboratif yaitu kerja sama antara peneliti dengan teman sejawat, ide berasal dari peneliti dan yang melakukan tindakan adalah guru mata pelajaran tematik kelas V SDN Tambakreja 09 Cilacap. di lakukan pada semester I. Unit penelitian adalah kelas V SDN Tambakreja 09 Cilacap. Subjek dalam penelitian ini adalah siswa kelas V SDN Tambakreja 09 Kabupaten Cilacap Tahun Pelajaran 2020/2021 dengan jumlah 23 siswa. Dalam penelitian ini peneliti akan mengambil tempat di SDN Tambakreja 09 Kabupaten Cilacap Propinsi Jawa Tengah. Adapun waktu pelaksanaan bulan Oktober 2020-November 2020. Teknik pengumpulan data yang dipakai dalam penelitian tindakan ini adalah teknik tes dan non tes yang terdiri dari: Tes berbentuk pilihan ganda, digunakan untuk mengukur kemampuan siswa setelah diberi strategi stimulus gambar powerpoint dengan menggunakan discovery learning. Non tes dalam penelitian ini berupa pengamatan implementasi RPP, pengamatan aktivitas siswa dan penilaian proses. Pengamatan implementasi RPP digunakan untuk mendapat data tentang pengajaran guru didalam kelas serta pengamatan keaktifan siswa, sehingga bisa dilihat di dalam pelaksanaan pembelajaran benar-benar sesuai dengan kondisi dan proses yang diharapkan. Pengamatan melalui diskusi dan presentasi dilakukan terhadap proses pembelajaran dengan menggunakan media video power point camtasia studio 8. Dokumentasi digunakan untuk mendapatkan data tentang identitas dari siswa. Dalam hal ini data yang diperoleh adalah daftar siswa menonjol baik dari segi positif maupun negatifnya. Teknik analis data yang peneliti gunakan dalam penelitian untuk mengetahui tingkat keberhasilan belajar siswa kelas V SDN Tambakreja 09 Cilacap yaitu teknik deskriptif komparatif yakni teknik statistik dengan membandingkan skor antar siklus, persentase, mean, skor minimal, maksimal. 


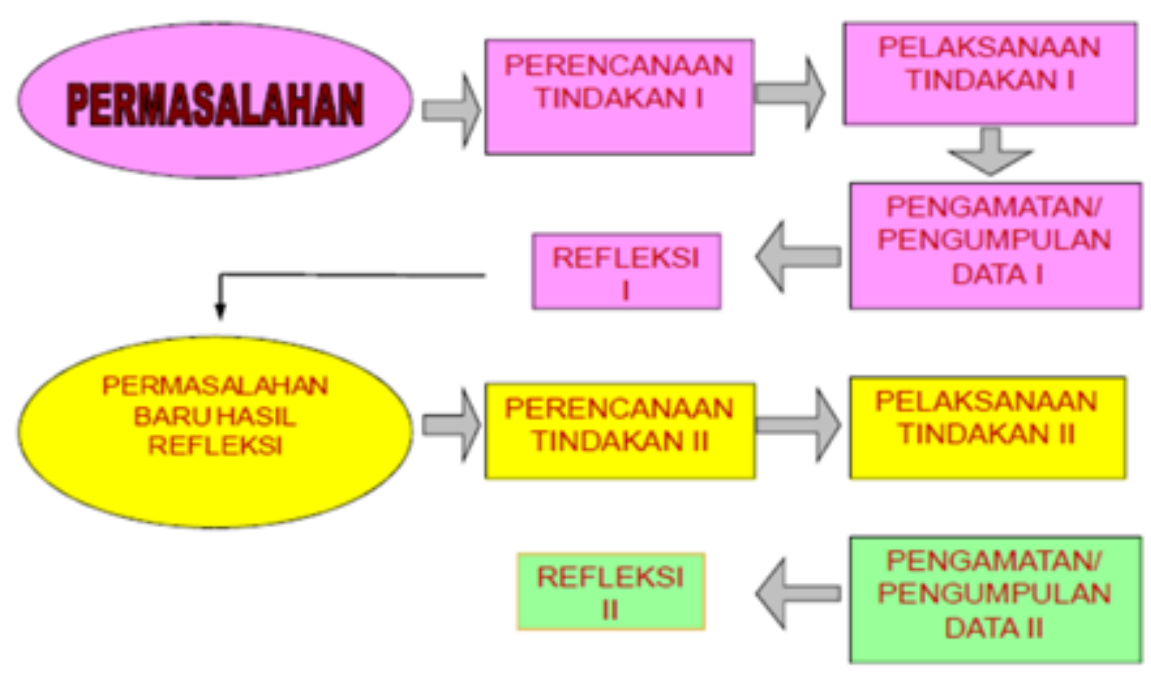

Gambar 1. Alur Pelaksanaan Penelitian

Sumber : Hartono dan Edi Legowo ( $2003: 4$ )

\section{HASIL DAN PEMBAHASAN}

Menurut Nana Sudjana (2008) mengemukakan penilaian hasil belajar mengisyaratkan bahwa hasil belajar sebagai objek yang menjadi sasaran penilaian. Hasil belajar sebagai objek penilaian pada hakikatnya menilai penguasaan siswa terhadap tujuan-tujuan intruksional, karena rumusan tujuan intruksional menggambarkan hasil belajar yang harus dikuasai siswa berupa kemampuankemampuan siswa setelah menerima atau menyelesaikan pengalaman belajarnya. Hasil belajar sebagai objek penilaian pada hakikatnya menilai penguasaan siswa terhadap tujuan-tujuan intruksional, karena rumusan tujuan intruksional menggambarkan hasil belajar yang harus dikuasai siswa berupa kemampuankemampuan siswa setelah menerima atau menyelesaikan pengalaman belajarnya. Sedangkan Bloom, dkk (dalam Asep Heri Hernawan, 2009) menggolongkan hasil belajar menjadi tiga, yaitu kognitif, afektif, dan psikomotor.

Dari beberapa pengertian hasil belajar, penulis menyimpulkan bahwa hasil belajar adalah tanda atau bukti yang diperoleh siswa yang berguna untuk mengukur kemampuan siswa setelah selesai pembelajaran.

Tabel 1. Presentasi Ketuntasan Belajar Siklus II

\begin{tabular}{clcccc}
\hline \multirow{2}{*}{ No } & \multicolumn{1}{c}{ Uraian } & \multicolumn{2}{c}{$\begin{array}{c}\text { Siswa yang Tuntas } \\
\text { Frekuensi }\end{array}$} & Persentase & \multicolumn{2}{c}{$\begin{array}{c}\text { Siswa Belum Tuntas } \\
\text { Frekunsi }\end{array}$} & Persentase \\
\hline 1 & $\begin{array}{l}\text { Kondisi Awal } \\
\text { (sesuai dengan } \\
\text { keadaan pada latar }\end{array}$ & 16 & $67 \%$ & 7 & $33 \%$ \\
2 & $\begin{array}{l}\text { belakang) } \\
\text { Siklus I }\end{array}$ & 17 & $71 \%$ & 6 & $29 \%$ \\
3 & Siklus II & 18 & $75 \%$ & 5 & $25 \%$ \\
\hline
\end{tabular}


Tabel di atas dapat dijelaskan siswa yang belum tuntas belajar adalah sebagai berikut : Pada kondisi awal sesuai dengan latar belakang penelitian, siswa yang belum tuntas sebanyak 7 siswa dari 23 siswa atau 33\%. Pada siklus I, siswa yang belum tuntas sebanyak 6 siswa dari 23 siswa atau 29\%. Pada siklus II, siswa yang elum tuntas sebanyak 5 siswa dari 23 siswa atau $25 \%$.

Sedangkan siswa yang tuntas belajar adalah sebagai berikut: Pada kondisi awal sesuai dengan latar belakang penelitian, siswa yang tuntas sebanyak 16 siswa dari 23 siswa atau 67\%. Pada siklus 1, siswa yang tuntas sebanyak 17 siswa dari 23 siswa atau $71 \%$. Pada siklus II, siswa yang tuntas sebanyak 16 siswa dari 23 siswa atau $75 \%$. Berdasarkan tabel diatas dapat dibuat diagram batang hasil belajar siklus II sebagai berikut :

\section{grafik hasil belajar siklus II}

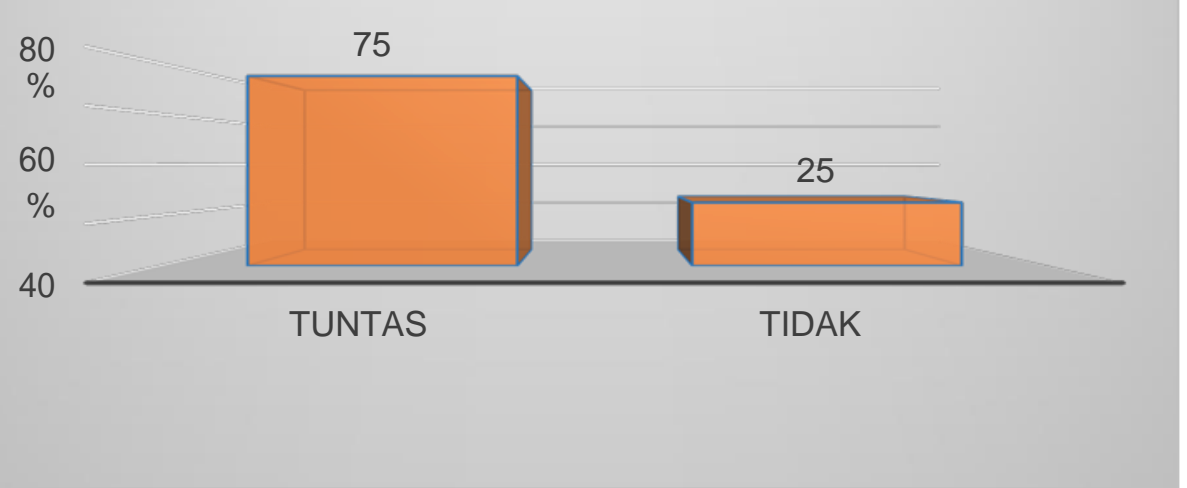

Gambar 2. Hasil Belajar Siswa Siklus 2

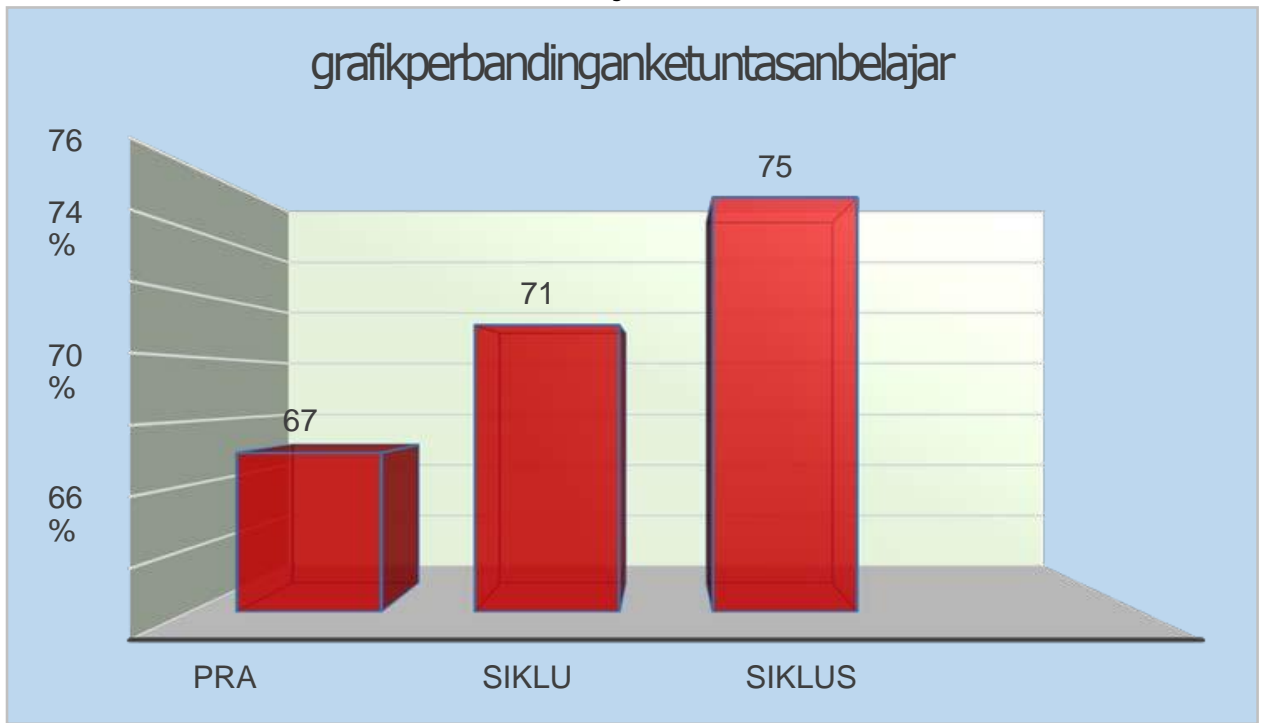

Gambar 3. Perbandingan Ketuntasan Belajar

\section{SIMPULAN}

Kesimpulan dari penelitian ini adalah pembelajaran daring menggunakan media video powerpoint dengan model discovery learning dapat meningkatkan hasil belajar siswa pada Tema 5 ekosistem kelas V SDN Tambakreja 09 Cilacap. Dalam pembelajaran daring hendaknya guru dapat menggunakan media video powerpoint dengan model discovery learning sesuai langkah-langkahnya pada mata pelajaran tematik sehingga dapat meningkatkan partisipasi aktif, memunculkan ide, penguasaan konsep dan meningkatkan hasil belajar tematik 
siswa. Saran dari penelitian ini adalah hendaknya guru mengembangkan pembelajaran menggunakan media video powerpoint dengan model discovery learning pada pelajaran yang

\section{DAFTAR PUSTAKA}

Arif Sadiman., dkk. 2003. Media Pendidikan (Pengertian Pengembangan dan Pemafaatannya). Jakarta: CV Rajawali.

Arsyhar, Rayandra. 2012. Media Pembelajaran. Edisi 1. Jakarta:Referensi Jakarta

Asyhar, Rayandra 2012. Kreatif Mengembangkan Media Pembelajaran. Jakarta: Refrensi Jakrata.

Dimyati, Mudjiono. 1991. Belajar dan Pembelajaran. Jakarta: PT Rineka Cipta. Firdaus. 2006. Reformasi Pembelajaran Menuju Kualitas Insan Bertaraf Dunia. Pekanbaru: Witra Irzani.

Hamalik, Oemar. 2001. Proses Belajar Mengajar. Jakarta: Bumi Aksara. Hernawan, Asep Heri, dkk. 2009. Pengembangan Kurikulum dan Pembelajaran. Jakarta: Universitas Terbuka.

Majid, Abdul. 2014. Strategi Pembelajaran. Bandung: Remaja Rosdakarya.

M. Iskandar Putra, dkk. Pengembangan Media Pembelajaran Berbasisi Camtasia Studio Video CD INTERAktif Multimedia untuk MaTa Pelajaran Pemrograman WEBb di Jurusan Multimedia SMK NEGERI 3 Singaraja Prodi Pendidikan Teknik Elektro, Universitas Pendidikan Ganesha, Singaraja. Prodi Teknik Elektronika,Universitas Pendidikan Ganesha, Singaraja Jurnal Pendidikan Teknik Elektro Undiksha Vol. 6 No. 1, April 2017

Sudjana, Nana. 2008. Penilaian Hasil Proses Belajar Mangajar. Bandung: PT Remaja Rosdakarya. 